\title{
A Study on the Removal Characteristics of Malachite Green Dye from Wastewater by Low-Cost Nano Porous Adsorbent
}

\author{
R. SIVAKUMAR and S. ARIVOLI*
}

PG and Research Department of Chemistry, Thiru Vi Ka Government Arts College, Thiruvarur, Tamilnadu, India

arivu6363@gmail.com

Received 5 December 2016 / Accepted 22 December 2016

\begin{abstract}
Modified activated Syringodium Isoetifolium leaves nano carbon (ASI-NC) has been applied for removal of the malachite green dye from aqueous environments. The effect of $\mathrm{pH}$, contact time, initial concentration and amount of adsorbent were considered. In order to investigate the mechanism of the adsorption process, several kinetic models including pseudo-first order, pseudo-second order and intra-particle diffusion were used. In addition, equilibrium data was fitted with Langmuir, Freundlich, Temkin, Dubinin-Radushkevich, Hurkins-Jura, Halsay, RadlichPeterson, Jovanovic and BET isotherm models. Results showed that the adsorption of the malachite green was enhanced with increasing initial dye concentration, $\mathrm{pH}$ and contact time. The optimum $\mathrm{pH}$ was 9. The $\mathrm{q}_{\max }$ for adsorption of malachite green dye from the Langmuir model was $15.87 \mathrm{mg} / \mathrm{g}$. considering the values of $\mathrm{R}^{2}(0.999)$ and $\chi^{2}$, Freundlich isotherm model and pseudo-second order kinetic model had the best fitness. This study has demonstrated that the modified activated Syringodium Isoetifolium leaves nano carbon (ASI-NC) with $\mathrm{H}_{2} \mathrm{SO}_{4}$ can be employed as effective and inexpensive adsorbent for the removal of malachite green from aqueous environments.
\end{abstract}

Keywords: Malachite Green, Activated Syringodium Isoetifolium leaves nano carbon

\section{Introduction}

Industrial wastewater is considered as one of the major pollutants of the environment ${ }^{1}$. Moreover, textile industries are among each country's basic industries and have coloured wastewater due to making use of coloured materials ${ }^{2}$. Overall, coloured wastewater is produced by various industries, such as textile, dyeing, pharmaceutical, food, cosmetics and healthcare, paper and leather industries. Such colors not only change the water's colour, which is important regarding aesthetics, but they also prevent light from penetrating through water, disturb photosynthesis and destroy the aquatic ecosystem as well as several aquatic species $^{3}$. One of the high consuming materials in the dye industry is malachite green (MG) which is used for cotton and silk painting ${ }^{4}$. Up to now, a great number of methods have been proposed in order to remove dyes from the industrial wastewater among which adsorption is the most acceptable due to its cost effectiveness and its capability to be used in large scales 5 . 
The methods of colour removal from industrial effluents include biological treatment, coagulation, flotation, adsorption, oxidation and hyper filtration ${ }^{6}$. Among the treatment options, adsorption has been found to be superior to other techniques for water treatment in terms of initial cost, simplicity of design, ease of operation and insensitivity of toxic substances ${ }^{7}$. Different adsorbents have been used for the removal of various materials from aqueous solutions, such as dyes, metal ions and other organic materials including perlite ${ }^{8}$, bentonite $^{9}$, silica gels ${ }^{10}$, fly ash and lignite ${ }^{11}$, peat ${ }^{12}$, silica ${ }^{13}$, etc.

Among these natural materials, activated Syringodium Isoetifolium leaves nano carbon (ASI-NC) which has a low weight and a fine micro-porous structure (up to 90\%) and can be found in many regions of coastal part of Tamilnadu, India. Because of its fine micro-porous structure, Activated Syringodium Isoetifolium leaves nano carbon has a high specific surface area and can float in water owing to its low density.

\section{Objectives}

Due to several advantages of the Syringodium Isoetifolium Leaves and its accessibility in India, the aim of the present work was to investigate its effectiveness for the removal of MG at various experimental conditions. Since initial activated Syringodium Isoetifolium leaves has some impurity, shows low sorption capacity and is negatively charged, the acidic treated activated Syringodium Isoetifolium leaves was used in this work. Therefore, the purpose for acidic treatment of activated Syringodium Isoetifolium leaves was to improve the positive surface charge of adsorbent and its sorption capacity since initial activated Syringodium Isoetifolium leaves shows low sorption capacity. The present study aims to use modified activated Syringodium Isoetifolium leaves nano carbon for removing MG dye from aqueous solutions.

\section{Experimental}

Stock solution was prepared by dissolving the required amount of MG in double distilled water. The test solutions were prepared by diluting stock solution to the desired concentrations. The concentration of the MG was determined at $620 \mathrm{~nm}$. The $\mathrm{pH}$ measurements were done using Digital pH meter (Equip-Tronics EQ 614A, India) and adsorption studies were carried out on UV-Vis Double Beam spectrophotometer (Systronics 2203, India). All chemicals include $\mathrm{NaOH}, \mathrm{HCl}$ and $\mathrm{MG}$ was of highest available purity (Merck).

\section{Preparation of adsorbent}

Syringodium Isoetifolium leaves were collected from East Coastal area of Nagapattinam district and washed several times by de-ionized water in order to remove the primary impurities. The shell was placed in Con. $\mathrm{H}_{2} \mathrm{SO}_{4}(\mathrm{w} / \mathrm{v})$ for 24 hours for carbonization and increasing the adsorbent's porosity. The prepared sample was washed several times by deionized water, grounded well to fine powder and sieved by a mesh. Finally, this was activated around $1200{ }^{\circ} \mathrm{C}$ in muffle furnace for 12 hours. The fine micro-porous size of 40 $\mathrm{nm}$ activated nano carbon was utilized as the adsorbent. The photograph of Syringodium Isoetifolium leaves is shown in Figure 1.

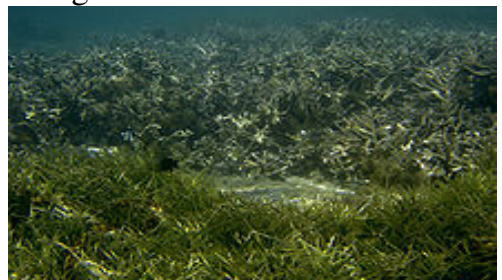

Figure 1.Photograph of Syringodium Isoetifolium 


\section{Adsorption study}

To study the effect of important parameters like $\mathrm{pH}$, contact time and initial dye concentration on the adsorptive removal of $\mathrm{MG}$, batch experiments were conducted. For each experimental run, $50 \mathrm{~mL}$ of different concentrations of the dye solution $(25-125 \mathrm{mg} / \mathrm{L})$ was agitated with $0.025 \mathrm{~g}$ of the adsorbent at $120 \mathrm{rpm}$ until the equilibrium was achieved. Samples were withdrawn at different time intervals (15, 30, 45 and 60 minutes) and kinetics, isotherm and other parameters of adsorption was determined by analyzing the remaining dye concentration from aqueous solution. In order to evaluate the effect of the initial $\mathrm{pH}$ on MG adsorption, the equilibrium study was conducted at different $\mathrm{pH}$ levels $3,4,5,6,7,8$ and 9 and other equilibrium studies were continued at the optimum $\mathrm{pH}$ 6.5. The $\mathrm{pH}$ of the solutions was adjusted by adding $0.01 \mathrm{~N}$ aqueous solutions of $\mathrm{NaOH}$ and $\mathrm{HCl}$. The percentage removal of dye was calculated using the following equation:

$$
\% \text { MG removal }=\left(\mathrm{C}_{0}-\mathrm{C}_{\mathrm{t}}\right) / \mathrm{C}_{0} \times 100
$$

Where, $\mathrm{C}_{0}(\mathrm{mg} / \mathrm{L})$ and $\mathrm{C}_{\mathrm{t}}(\mathrm{mg} / \mathrm{L})$ are the initial dye concentration and dye concentration at time $\mathrm{t}$, respectively. When the system reached the equilibrium concentration, the equilibrium adsorption capacity was calculated through the following equation:

$$
\mathrm{q}_{\mathrm{e}}=\mathrm{v}\left(\mathrm{C}_{0}-\mathrm{C}_{\mathrm{e}}\right) / \mathrm{w}
$$

In this equation, $\mathrm{q}_{\mathrm{e}}(\mathrm{mg} / \mathrm{g})$ represents the rate of the adsorbed dye per mass unit of the absorbent, $\mathrm{C}_{0}(\mathrm{mg} / \mathrm{L})$ and $\mathrm{C}_{\mathrm{e}}(\mathrm{mg} / \mathrm{L})$ are initial and equilibrium dye concentrations, respectively and $\mathrm{v}(\mathrm{L})$ and $\mathrm{w}(\mathrm{g})$ are the volume of the dye solution and the weight of the adsorbent, respectively.

\section{Results and Discussion}

\section{The effect of $\mathrm{pH}$ on the removal efficiency}

Solution $\mathrm{pH}$ affects both aqueous chemistry and surface binding sites of the adsorbents. The effect of initial $\mathrm{pH}$ on adsorption of $\mathrm{MG}$ was studied from $\mathrm{pH} 3$ to 9 at initial MG dye concentration of $25 \mathrm{mg} / \mathrm{L}$, adsorbent dosage of $0.025 \mathrm{~g}$ and contact time of $60 \mathrm{~min}$. Two possible mechanisms of adsorption of MG dye on the ASI-NC adsorbent may be considered include: (a) electrostatic interaction between the adsorbent and the MG molecule, (b) a chemical reaction between the MG and the adsorbent. When $\mathrm{pH}$ increases, the concentration of $\mathrm{OH}^{-}$ions in the desired solution is increased, as well. This causes the surface of the ASI-NC to become deprotonated and, as a result, the negative charge of the used ASI-NC surface will be amplified. Therefore, the electrostatic attractive force between the MG dye, which has a positive charge and the adsorbent surface increases and consequently, the rate of dye adsorption increases, as well. As Figure 2 depicts, the $\mathrm{pH}$ of the solution increased from 3 to 10 , the rate of removal also increased up to $\mathrm{pH} 6.5$ then decrease.

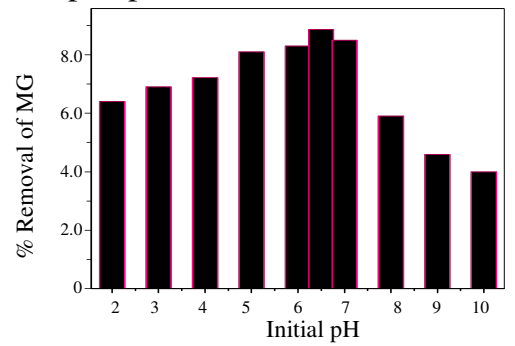

Figure 2. Effect of initial $\mathrm{pH}$ on the removal of $\mathrm{MG}$ dye ([MG] $=50 \mathrm{mg} / \mathrm{L}$; Temperature $30^{\circ} \mathrm{C}$; Absorbent dose $=0.025 \mathrm{~g} / 50 \mathrm{~mL}$ ) 


\section{Effect of adsorbent dosage on the removal of $M G$ dye}

The adsorption of the MG dye on ASI-NC was studied by varying the adsorbent dose (25$125 \mathrm{mg} / 50 \mathrm{~mL}$ ) for $50 \mathrm{mg} / \mathrm{L}$ of dye concentration. The percentage of adsorption increased with increases in the ASI-NC dose, which is attributed to increased carbon surface area and the availability of more adsorption sites. Hence, all studies were carried out with $0.025 \mathrm{~g}$ of adsorbent $/ 50 \mathrm{~mL}$ of the varying adsorbate solutions $25,50,75,100$ and $125 \mathrm{mg} / \mathrm{L}$. The results obtained from this study are shown in Figure 3. The amount of MG dye adsorbed per gram reduced with increase in the dosage of ASI-NC. This reveals that the direct and equilibrium capacities of MG dye are functions of the activated ASI-NC dosage.

\section{The effect of contact time on the removal of $M G$ dye}

Generally, diffusion of the adsorbate on the used adsorbent and ultimately the adsorption phenomena on the adsorbent are time consuming processes. The adsorption rate, obtained for MG adsorption on ASI-NC was observed by decrease of the concentration of MG within the adsorption medium with contact time. The time necessary to reach the equilibrium for the removal of the MG molecules at different concentrations (25-125 mg/L) by ASI-NC from aqueous solution was established to be about 60 minutes. As Figure 4 shows, at all the used concentrations, as the contact time between the adsorbent and the adsorbate increased, the adsorption rate increased, as well. According to Figure 4, the highest rate of MG removal took place during the 15-30 minute interval. In the remaining concentrations, this reduction continued up to 45 minutes with a lower slope. From this time up to 60 minutes, the system was almost constant and did not have much adsorption. At $25 \mathrm{mg} / \mathrm{L}$ of $\mathrm{MG}$, the removal rate varied from $32.6 \%$ to $92.3 \%$ of the maximum removal onto ASI-NC the values are shown in Table 1. For instance, the adsorbents exhibited three stages, which can be attributed to each linear portion of the Figure 4. The first linear portion was attributed to the diffusion process of MG to the adsorbent surfaces, hence, was the fastest sorption stage. This result is corroborated by the fractionary-order kinetic model. The second linear portion was attributed to intra-particle diffusion, which was a delayed process. The third stage may be regarded as the diffusion through smaller pores, which is followed by the establishment of the equilibrium. The surface of ASI-NC may contain a large number of active sites and the solute uptake can be related to the active sites on equilibrium time. The higher sorption rate at the initial period (first 60 minutes) may be due to an increased number of vacant sites available at the initial stage. As result there exists increased concentration gradient between adsorbate in solution and adsorbate in adsorbent surface. This increase in the concentration gradients tends to increase in MG sorption at the initial stages.

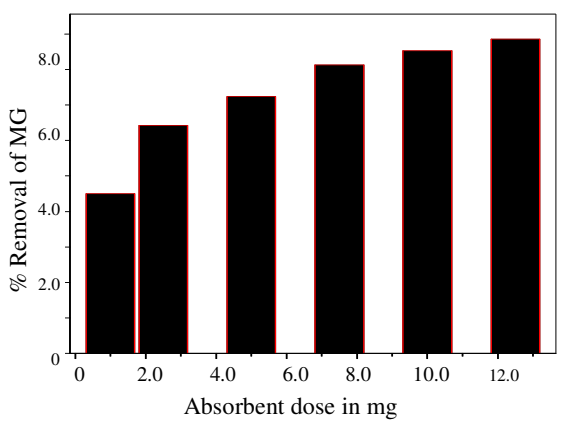

Figure 3. Effect of absorbent dose on the removal of $\mathrm{MG}$ dye $([\mathrm{MG}]=50 \mathrm{mg} / \mathrm{L}$; Contact time 60 min; Temperature $30^{\circ} \mathrm{C}$ )

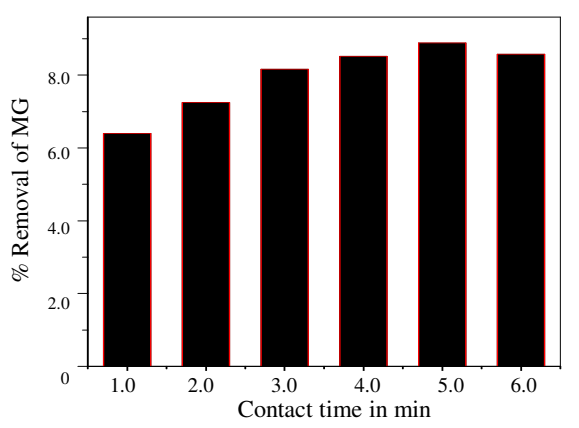

Figure 4. Effect of contact time on the removal of MG dye $\left([M G]=50 \mathrm{mg} / \mathrm{L}\right.$; Temperature $30{ }^{\circ} \mathrm{C}$; Absorbent dose $=0.025 \mathrm{~g} / 50 \mathrm{~mL}$ ) 
Table 1. Equilibrium parameters for the adsorption of MG dye onto ASI-NC

\begin{tabular}{cccccccccccccc}
\hline \multirow{2}{*}{$\mathrm{M}_{0}$} & \multicolumn{4}{c}{$\mathrm{C}_{\mathrm{e}}, \mathrm{Mg} / \mathrm{L}$} & \multicolumn{3}{c}{$\mathrm{Q}_{\mathrm{e}}, \mathrm{Mg} / \mathrm{L}$} & \multicolumn{3}{c}{ Removal \% } \\
\cline { 2 - 13 } & $30{ }^{\circ} \mathrm{C}$ & $40{ }^{\circ} \mathrm{C}$ & $50{ }^{\circ} \mathrm{C}$ & $60{ }^{\circ} \mathrm{C}$ & $30{ }^{\circ} \mathrm{C}$ & $40{ }^{\circ} \mathrm{C}$ & $50{ }^{\circ} \mathrm{C}$ & $60{ }^{\circ} \mathrm{C}$ & $30{ }^{\circ} \mathrm{C}$ & $40{ }^{\circ} \mathrm{C}$ & $50{ }^{\circ} \mathrm{C}$ & 60 & ${ }^{\circ} \mathrm{C}$ \\
\hline 25 & 4.041 & 2.694 & 2.022 & 1.953 & 41.92 & 44.61 & 45.96 & 46.09 & 83.84 & 89.22 & 91.91 & 92.19 \\
50 & 8.755 & 8.085 & 7.437 & 6.063 & 82.49 & 83.83 & 85.13 & 87.87 & 82.49 & 83.83 & 85.13 & 87.87 \\
75 & 18.24 & 16.71 & 14.82 & 13.88 & 113.5 & 116.6 & 120.4 & 122.2 & 75.68 & 77.73 & 80.24 & 81.50 \\
100 & 26.32 & 24.30 & 23.19 & 21.92 & 147.4 & 151.4 & 153.6 & 156.2 & 73.68 & 75.70 & 76.81 & 78.08 \\
125 & 38.39 & 37.17 & 36.43 & 34.46 & 173.2 & 175.7 & 177.1 & 181.1 & 69.29 & 70.26 & 70.86 & 72.43 \\
\hline
\end{tabular}

The effect of initial concentration on $M G$ removal efficiency

The effect of the initial concentration of MG dye on the adsorption efficiency of the ASI-NC was evaluated at different concentrations of $25,50,75,100$ and $125 \mathrm{mg} / \mathrm{L}$. In the present study, with the increase of the initial concentration from $25 \mathrm{mg} / \mathrm{L}$ to $125 \mathrm{mg} / \mathrm{L}$, the rate of dye removal was reduced from $83.84 \%$ to $69.29 \%$ the values are shown in Table 1 . In addition, as the pollutant concentration increased in the aquatic environment, the number of available sites on the adsorbent surface decreased. In other words, with the decrease of the pollutant concentration in the aquatic environment, molecules of the adsorbate have more chance to react with the available active sites on ASI-NC and as a result, the adsorption rate is increased. Hence, one can claim that one method to increase the percentage of dye removal is dilution of wastewater.

\section{Adsorption isotherms}

It is important to determine the most appropriate correlation for equilibrium adsorption isotherm, to optimize the design of a sorption system. The Freundlich, Langmuir, Temkin, Hurkins-Jura, Halsay, Redlich-Peterson, Dubinin-Radushkevich, Jovanovich and BET isotherm models were used to analyses the adsorption equilibrium. Experimental isotherm data were obtained at an adsorption time of $60 \mathrm{~min}$ at different temperatures.

\section{Freundlich adsorption isotherm}

The Freundlich adsorption isotherm is based on the equilibrium sorption on heterogeneous surfaces. This isotherm is derived from the assumption that the adsorption sites are distributed exponentially with respect to heat of adsorption. The adsorption isotherm is expressed by the following equation ${ }^{14}$

$$
\mathrm{q}_{\mathrm{e}}=\mathrm{K}_{\mathrm{F}} \mathrm{C}_{\mathrm{e}}^{1 / \mathrm{nF}}
$$

Which, can be linearized as

$$
\operatorname{lnq}_{\mathrm{e}}=\mathrm{nnK}_{\mathrm{F}}+\frac{1}{\mathrm{n}_{\mathrm{F}}} \ln _{\mathrm{e}}
$$

Where, $\mathrm{q}_{\mathrm{e}}$ is the amount of MG dye adsorbed at equilibrium $(\mathrm{mg} / \mathrm{g})$ and $\mathrm{C}_{\mathrm{e}}$ is the concentration of $\mathrm{MG}$ dye in the aqueous phase at equilibrium (ppm). $\mathrm{K}_{\mathrm{F}}(\mathrm{L} / \mathrm{g})$ and $1 / \mathrm{n}_{\mathrm{F}}$ are the Freundlich constants related to adsorption capacity and sorption intensity, respectively.

The Freundlich constants $\mathrm{K}_{\mathrm{F}}$ and $1 / \mathrm{n}_{\mathrm{F}}$ were calculated from the slope and intercept of the $\operatorname{lnq}_{\mathrm{e}} v s . \ln _{\mathrm{e}}$ plot and the model parameters are shown in Table 2. The magnitude of $\mathrm{K}_{\mathrm{F}}$ showed that ASI-NC had a high capacity for MG dye adsorption from the aqueous solutions studied. The Freundlich exponent, $\mathrm{n}_{\mathrm{F}}$, should have values in the range of 1 and 10 (i.e., $1 / \mathrm{n}_{\mathrm{F}}$ $<1$ ) to be considered as favourable adsorption ${ }^{15}$. A $1 / \mathrm{n}_{\mathrm{F}}$ value of less than 1 indicated that MG dye is favorably adsorbed by ASI-NC. The Freundlich isotherm did not show a good fit to the experimental data as indicated by SSE and Chi-square statistics. 
Table 2. Isotherms parameter for the adsorption of MG dye onto ASI-NC

\begin{tabular}{llcccc}
\hline \multirow{2}{*}{ Model } & \multicolumn{1}{c}{ Constant } & \multicolumn{4}{c}{ Temperature, ${ }^{\circ} \mathrm{C}$} \\
\cline { 3 - 6 } & & 30 & 40 & 50 & 60 \\
\hline \multirow{2}{*}{ Freundlich } & $\mathrm{K}_{\mathrm{f}}, \mathrm{mg} / \mathrm{g}, \mathrm{L} / \mathrm{mg}^{1 / \mathrm{n}}$ & 19.14 & 26.94 & 32.96 & 34.89 \\
\cline { 2 - 6 } & $\mathrm{n}$ & 1.619 & 1.894 & 2.095 & 2.094 \\
\hline \multirow{2}{*}{ Langmuir } & $\mathrm{Q}_{\mathrm{m}}, \mathrm{mg} / \mathrm{g}$ & 267.2 & 235.9 & 222.9 & 224.2 \\
\cline { 2 - 6 } & $\mathrm{b}, \mathrm{L} / \mathrm{mg}$ & 0.046 & 0.072 & 0.096 & 0.108 \\
\hline \multirow{2}{*}{ Temkin } & $\mathrm{b}_{\mathrm{T}}, \mathrm{J} / \mathrm{mol}$ & 57.19 & 49.88 & 45.77 & 46.83 \\
\cline { 2 - 6 } & $\mathrm{K}_{\mathrm{T}}, \mathrm{L} / \mathrm{mg}$ & 0.390 & 0.790 & 1.094 & 1.161 \\
\hline \multirow{2}{*}{ Hurkins-Jura } & $\mathrm{A}_{\mathrm{H}}, \mathrm{g}^{2} \mathrm{~L}$ & -1938 & -2435 & -2804 & -2898 \\
\cline { 2 - 6 } & $\mathrm{B}_{\mathrm{H}}, \mathrm{mg}{ }^{2} / \mathrm{L}$ & -1.501 & -1.490 & -1.478 & -1.447 \\
\hline \multirow{2}{*}{ Halsay } & $\mathrm{K}_{\mathrm{Ha}}, \mathrm{mg} / \mathrm{L}$ & 118.9 & 512.8 & 1515.6 & 1700.6 \\
\cline { 2 - 6 } & $\mathrm{n}_{\mathrm{Ha}}$ & 1.619 & 1.894 & 2.095 & 2.094 \\
\hline \multirow{2}{*}{ Radlich-Peterson } & $\mathrm{g}$ & 0.382 & 0.472 & 0.523 & 0.522 \\
\cline { 2 - 6 } & $\mathrm{K}_{\mathrm{R}}, \mathrm{L} / \mathrm{g}$ & 140.4 & 0.037 & 0.030 & 0.029 \\
\hline \multirow{2}{*}{$\begin{array}{l}\text { Dubinin- } \\
\text { Radushkevich }\end{array}$} & $\mathrm{q}_{\mathrm{s}}, \mathrm{mg} / \mathrm{g}$ & 1.611 & 1.595 & 135.5 & 140.6 \\
\cline { 2 - 6 } & $\mathrm{K}_{\mathrm{D}} \mathrm{x} 10^{-4} \mathrm{~mol}^{2} \mathrm{~kJ}^{-2}$ & 0.037 & 0.037 & 0.036 & 0.038 \\
\hline \multirow{2}{*}{ Jovanovic } & $\mathrm{K}_{\mathrm{J}}, \mathrm{L} / \mathrm{g}$ & 48.89 & 53.43 & 57.30 & 59.32 \\
\cline { 2 - 6 } & $\mathrm{q}_{\mathrm{max}}, \mathrm{mg} / \mathrm{g}$ & 6.352 & 10.75 & 15.83 & 17.66 \\
\hline \multirow{2}{*}{ BET } & $\mathrm{C}_{\mathrm{BET}}, \mathrm{L} / \mathrm{mg}$ & 0.157 & 0.093 & 0.063 & 0.057 \\
\cline { 2 - 6 } & $\mathrm{qs}, \mathrm{mg} / \mathrm{g}$ & & & \\
\hline
\end{tabular}

\section{Langmuir adsorption isotherm}

The Langmuir adsorption isotherm is based on the assumption that all sorption sites possess equal affinity to the adsorbate. The Langmuir isotherm in a linear form can be represented as ${ }^{16}$

$$
\frac{C_{e}}{q_{e}}=\frac{1}{q_{m} K_{L}}+\frac{C_{e}}{q_{m}}
$$

Where $\mathrm{q}_{\mathrm{e}}$ is the amount of MG dye adsorbed at equilibrium $(\mathrm{mg} / \mathrm{g}), \mathrm{C}_{\mathrm{e}}$ is the concentration of MG in the aqueous phase at equilibrium (ppm), $\mathrm{q}_{\mathrm{m}}$ is the maximum $\mathrm{MG}$ dye uptake $(\mathrm{mg} / \mathrm{g})$ and $\mathrm{K}_{\mathrm{L}}$ is the Langmuir constant related to adsorption capacity and the energy of adsorption $(\mathrm{g} / \mathrm{mg})$.

A linear plot of $\mathrm{C}_{\mathrm{e}} / \mathrm{q}_{\mathrm{e}} v s . \mathrm{C}_{\mathrm{e}}$ was employed to determine the value of $\mathrm{q}_{\mathrm{m}}$ and $\mathrm{K}_{\mathrm{L}}$ and the data so obtained were also presented in Table 2 . The model predicted a maximum value that could not be reached in the experiments. The value of $\mathrm{K}_{\mathrm{L}}$ decreased with an increase in the temperature. A high $\mathrm{K}_{\mathrm{L}}$ value indicates a high adsorption affinity. Abdel wahab ${ }^{17}$ expressed the Langmuir isotherm in term of dimensionless constant separation factor or equilibrium parameter $\left(\mathrm{R}_{\mathrm{L}}\right)$ defined in the following equation:

$$
\mathrm{R}_{\mathrm{L}}=\frac{1}{1+\mathrm{K}_{\mathrm{L}} \mathrm{C}_{0}}
$$

Where, $\mathrm{C}_{0}$ is the initial $\mathrm{MG}$ dye concentration (ppm). Four scenarios can be distinguished: The sorption isotherm is unfavorable when $R_{L}>1$, the isotherm is linear when $\mathrm{R}_{\mathrm{L}}=1$, the isotherm is favorable when $0<\mathrm{R}_{\mathrm{L}}<1$ and the isotherm is irreversible when $R_{L}=0$. The values of dimensionless separation factor $\left(R_{L}\right)$ for MG dye removal were calculated at different concentrations and temperatures. As shown in Table 3, at all concentrations and temperatures tested the values of $\mathrm{R}_{\mathrm{L}}$ for MG dye adsorptions on the ASI$\mathrm{NC}$ were less than 1 and greater than zero, indicating favorable adsorption. 
Table 3. Dimensionless separation factor $\left(\mathrm{R}_{\mathrm{L}}\right)$ for the adsorption of MG dye onto ASI-NC

\begin{tabular}{ccccc}
\hline \multirow{2}{*}{$\left(\mathrm{C}_{\mathrm{i}}\right)$} & \multicolumn{5}{c}{ Dimensionless separation factor, $\mathrm{R}_{\mathrm{L}}$} \\
\cline { 2 - 5 } & $30{ }^{\circ} \mathrm{C}$ & $40{ }^{\circ} \mathrm{C}$ & $50{ }^{\circ} \mathrm{C}$ & $60{ }^{\circ} \mathrm{C}$ \\
\hline 25 & 0.464 & 0.358 & 0.295 & 0.270 \\
50 & 0.302 & 0.218 & 0.173 & 0.156 \\
75 & 0.224 & 0.157 & 0.122 & 0.110 \\
100 & 0.178 & 0.122 & 0.095 & 0.085 \\
125 & 0.148 & 0.100 & 0.077 & 0.069 \\
\hline
\end{tabular}

The Langmuir isotherm showed a better fit to the adsorption data than the Freundlich isotherm. The fact that the Langmuir isotherm fits the experimental data well may be due to homogeneous distribution of active sites on the ASI-NC surface, since the Langmuir equation assumes that the adsorbent surface is energetically homogeneous.

\section{Temkin adsorption isotherm}

The Temkin adsorption isotherm assumes that the heat of adsorption decreases linearly with the sorption coverage due to adsorbent-adsorbate interactions ${ }^{18}$. The Temkin isotherm equation is given as:

$$
\mathrm{q}_{\mathrm{e}}=\frac{\mathrm{RT}}{\mathrm{bT}} \ln \left(\mathrm{K}_{\mathrm{T}} \mathrm{C}_{\mathrm{e}}\right)
$$

Which, can be represented in the following linear form

$$
\mathrm{q}_{\mathrm{e}}=\frac{\mathrm{RT}}{\mathrm{b}} \ln \mathrm{K}_{\mathrm{T}}+\frac{\mathrm{RT}}{\mathrm{b}} \ln \mathrm{C}_{\mathrm{e}}
$$

Where, $\mathrm{K}_{\mathrm{T}}(\mathrm{L} / \mathrm{g})$ is the Temkin isotherm constant, $\mathrm{b}_{\mathrm{T}}(\mathrm{J} / \mathrm{mol})$ is a constant related to heat of sorption, $\mathrm{R}$ is the ideal gas constant $(8.314 \mathrm{~J} / \mathrm{mol} \mathrm{K})$ and $\mathrm{T}$ is absolute temperature $(\mathrm{K})$. A plot of $\mathrm{q}_{\mathrm{e}}$ versus $\ln \mathrm{C}_{\mathrm{e}}$ enables the determination of isotherm constants $\mathrm{K}_{\mathrm{T}}$ and $\mathrm{b}_{\mathrm{T}}$ from the slope and intercept. The model parameters are listed in Table 2. The Temkin isotherm appears to provide a good fit to the MG dye adsorption data.

The adsorption energy in the Temkin model, $b_{\mathrm{T}}$, is positive for MG dye adsorption from the aqueous solution, which indicates that the adsorption is endothermic. The experimental equilibrium curve is close to that predicted by Temkin model. Consequently, the adsorption isotherm of MG dye on ASI-NC can be described reasonably well by the Temkin isotherm.

\section{Hurkins-Jura adsorption isotherm}

The Hurkins-Jura adsorption isotherm can be expressed as ${ }^{19}$.

$$
\mathrm{q}_{\mathrm{e}}=\sqrt{\frac{\mathrm{A}_{\mathrm{H}}}{\mathrm{B}_{\mathrm{H}}+\log \mathrm{C}_{\mathrm{e}}}}
$$

This can rearranged as follows:

$$
\frac{1}{\mathrm{q}_{\mathrm{e}}^{2}}=\frac{\mathrm{B}_{\mathrm{H}}}{\mathrm{A}_{\mathrm{H}}}-\frac{1}{\mathrm{~A}_{\mathrm{H}}} \log \mathrm{C}_{\mathrm{e}}
$$

Where, $A_{H}\left(g^{2} / L\right)$ and $B_{H}\left(\mathrm{mg}^{2} / L\right)$ are two parameters characterizing the sorption equilibrium.

The isotherm equation accounts for multilayer adsorption and can be explained by the existence of a heterogeneous pore distribution. The Harkins-Jura isotherm parameters are obtained from the plots of of $1 / \mathrm{q}_{\mathrm{e}}^{2}$ versus $\log \mathrm{C}_{\mathrm{e}}$ enables the determination of model parameters $\mathrm{A}_{\mathrm{H}}$ and $\mathrm{B}_{\mathrm{H}}$ from the slope and intercept. 


\section{Halsay adsorption isotherm}

The Halsay adsorption isotherm can be given $\mathrm{as}^{20}$.

$$
\mathrm{q}_{\mathrm{e}}=\exp \left(\frac{\ln \mathrm{K}_{\mathrm{Ha}}-\ln \mathrm{C}_{\mathrm{e}}}{\mathrm{n}_{\mathrm{Ha}}}\right)
$$

And, a linear form of the isotherm can be expressed as follows:

$$
\operatorname{lnq}_{\mathrm{e}}=\frac{\ln \mathrm{K}_{\mathrm{Ha}}}{\mathrm{n}_{\mathrm{Ha}}}-\frac{\operatorname{lnC}_{\mathrm{e}}}{\mathrm{n}_{\mathrm{Ha}}}
$$

Where, $\mathrm{K}_{\mathrm{Ha}}(\mathrm{mg} / \mathrm{L})$ and $\mathrm{n}_{\mathrm{Ha}}$ are the Halsay isotherm constants.

A plot of $\operatorname{lnq}_{\mathrm{e}} v s$. $\ln \mathrm{C}_{\mathrm{e}}$, enables the determination of $\mathrm{n}_{\mathrm{Ha}}$ and $\mathrm{K}_{\mathrm{Ha}}$ from the slope and intercept. This equation is suitable for multilayer adsorption and the fitting of the experimental data to this equation attest to the heteroporous nature of adsorbent. The experimental data and the model predictions based on the non-linear form of the Halsay models. The model parameters are listed in Table 2. This result also shows that the adsorption of MG dye on ASINC was not based on significant multilayer adsorption. The Halsay model is also not suitable to describe the adsorption of MG dye on ASI-NC, because this model also assumes a multilayer behavior for the adsorption of adsorbate onto adsorbent.

\section{Radlich-Peterson adsorption isotherm}

The Radlich-Peterson adsorption isotherm contains three parameters and incorporates the features of Langmuir and Freundlich isotherms into a single equation. The general isotherm equation can be described as follows ${ }^{21}$.

$$
\mathrm{q}_{\mathrm{e}}=\frac{\mathrm{K}_{\mathrm{R}} \mathrm{C}_{\mathrm{e}}}{1+\mathrm{a}_{\mathrm{R}} \mathrm{C}_{\mathrm{e}}^{\mathrm{g}}}
$$

The linear form of the isotherm can be expressed as follows:

$$
\ln \frac{\mathrm{C}_{\mathrm{e}}}{\mathrm{q}_{\mathrm{e}}}=\mathrm{glnC}_{\mathrm{e}}-\ln \mathrm{K}_{\mathrm{R}} \text {. }
$$

Where, $K_{R}(\mathrm{~L} / \mathrm{g})$ and $\mathrm{a}_{\mathrm{R}}(\mathrm{L} / \mathrm{mg})$ are the Radlich-Peterson isotherm constants and $\mathrm{g}$ is the exponent between 0 and 1 . There are two limiting cases: Langmuir form for $g=1$ and Henry's law for $\mathrm{g}=0$.

A plot of $\ln \mathrm{C}_{\mathrm{e}} / \mathrm{q}_{\mathrm{e}}$ versus $\ln \mathrm{C}_{\mathrm{e}}$ enables the determination of isotherm constants $\mathrm{g}$ and $\mathrm{K}_{\mathrm{R}}$ from the slope and intercept. The values of $K_{R}$, presented in Table 2, indicate that the adsorption capacity of the ASI-NC decreased with an increase temperature. Furthermore, the value of $\mathrm{g}$ lies between 0 and 1 , indicating favorable adsorption.

\section{Dubinin-Radushkevich adsorption isotherm}

The Dubinin-Radushkevich adsorption isotherm is another isotherm equation ${ }^{32}$. It is assumed that the characteristic of the sorption curve is related to the porosity of the adsorbent. The linear form of the isotherm can be expressed as follows ${ }^{22}$;

$$
\operatorname{lnq}_{\mathrm{e}}=\ln _{\mathrm{D}}-\mathrm{B}_{\mathrm{D}}\left[\mathrm{R} \ln \left(1+\frac{1}{\mathrm{C}_{\mathrm{e}}}\right)\right]^{2}
$$

Where, $\mathrm{Q}_{\mathrm{D}}$ is the maximum sorption capacity $(\mathrm{mol} / \mathrm{g})$ and $\mathrm{B}_{\mathrm{D}}$ is the DubininRadushkevich constant $\left(\mathrm{mol}^{2} / \mathrm{kJ}^{2}\right)$. A plot of $\ln \mathrm{q}_{\mathrm{e}} v s$. $\mathrm{R}_{\mathrm{T}} \ln \left(1+1 / \mathrm{C}_{\mathrm{e}}\right)$ enables the determination of isotherm constants $\mathrm{B}_{\mathrm{D}}$ and $\mathrm{Q}_{\mathrm{D}}$ from the slope and intercept. 


\section{Jovanovic adsorption isotherm}

The model of an adsorption surface considered by Jovanovic is essentially the same as that considered by Langmuir. The Jovanovic model leads to the following relationship ${ }^{23}$;

$$
\mathrm{q}_{\mathrm{e}}=\mathrm{q}_{\max }\left(1-\mathrm{e}^{\mathrm{K}_{\mathrm{J}} \mathrm{C}_{\mathrm{e}}}\right)
$$

The linear form of the isotherm can be expressed as follows:

$$
\ln \mathrm{q}_{\mathrm{e}}=\ln \mathrm{q}_{\max }-\mathrm{K}_{\mathrm{J}} \mathrm{C}_{\mathrm{e}}
$$

Where, $\mathrm{K}_{\mathrm{J}}(\mathrm{L} / \mathrm{g})$ is a parameter. $\mathrm{q}_{\max }(\mathrm{mg} / \mathrm{g})$ is the maximum Copper (II) uptake.

The $\mathrm{q}_{\max }$ is obtained from a plot of $\ln \mathrm{q}_{\mathrm{e}}$ and $\mathrm{C}_{\mathrm{e}}$. Their related parameters are listed in Table 2. By comparing the values of the error functions, it was found the Langmuir and Temkin models are best to fit the MG adsorption on the ASI-NC. Both models show a high degree of correlation. This is clearly confirming the good fit of Langmuir and Temkin models with the experimental data for removal of MG dye from the solution.

\section{The Brunauer-Emmett-Teller (BET) isotherm model}

Brunauer-Emmett-Teller (BET) ${ }^{24}$ isotherm is a theoretical equation, most widely applied in the gas-solid equilibrium systems. It was developed to derive multilayer adsorption systems with relative concentration ranges from 25 to $125 \mathrm{mg} / \mathrm{L}$ corresponding to a monolayer coverage lying between 50 and $150 \mathrm{mg} / \mathrm{L}$. Its extinction model related to liquid-solid interface is exhibited as:

$$
\mathrm{q}_{\mathrm{e}}=\frac{\mathrm{q}_{\mathrm{s}} \mathrm{C}_{\mathrm{BET}} \mathrm{C}_{\mathrm{e}}}{\left(\mathrm{C}_{\mathrm{s}}-\mathrm{C}_{\mathrm{e}}\right)\left[1+\left(\mathrm{C}_{\mathrm{BET}}-1\right)\left(\mathrm{C}_{\mathrm{e}} / \mathrm{C}_{\mathrm{s}}\right)\right]}
$$

Where, CBET, Cs, $\mathrm{q}_{\mathrm{s}}$ and $\mathrm{q}_{\mathrm{e}}$ are the BET adsorption isotherm $(\mathrm{L} / \mathrm{mg})$, adsorbate monolayer saturation concentration $(\mathrm{mg} / \mathrm{L})$, theoretical isotherm saturation capacity $(\mathrm{mg} / \mathrm{g})$ and equilibrium adsorption capacity $(\mathrm{mg} / \mathrm{g})$, respectively. As $\mathrm{C}_{\mathrm{BET}}$ and $\mathrm{C}_{\mathrm{BET}}\left(\mathrm{C}_{\mathrm{e}} / \mathrm{C}_{\mathrm{s}}\right)$ is much greater than 1, In the linear form as used is represented as:

$$
\frac{\mathrm{C}_{\mathrm{e}}}{\mathrm{q}\left(\mathrm{C}_{\mathrm{s}}-\mathrm{C}_{\mathrm{e}}\right)}=\frac{1}{\mathrm{q}_{\mathrm{s}} \mathrm{C}_{\mathrm{BET}}}+\left(\frac{\mathrm{C}_{\mathrm{BET}}-1}{\mathrm{q}_{\mathrm{s}} \mathrm{C}_{\mathrm{BET}}}\right)\left(\frac{\mathrm{C}_{\mathrm{e}}}{\mathrm{C}_{\mathrm{s}}}\right) .
$$

Where, $C_{e}$ is equilibrium Concentration $(\mathrm{mg} / \mathrm{L}), \mathrm{C}_{\mathrm{s}}$ is adsorbate monolayer saturation concentration $(\mathrm{mg} / \mathrm{L})$ and $\mathrm{C}_{\mathrm{BET}}$ is BET adsorption relating to the energy of surface interaction $(1 / \mathrm{mg})$ the BET model.

\section{Adsorption kinetics}

The rate and mechanism of the adsorption process can be elucidated based on kinetic studies. Dye adsorption on solid surface may be explained by two distinct mechanisms: (1) An initial rapid binding of dye molecules on the adsorbent surface; (2) relatively slow intraparticle diffusion. To analyze the adsorption kinetics of the dye, the pseudo-first-order, the pseudo-second-order, and intra-particle diffusion models were applied ${ }^{25}$. Each of these models and their linear modes of them equations presented in below.

$$
\text { Model Nonlinear Form Linear Form }
$$

$$
\begin{array}{lll}
\text { Pseudo-first-order } & \mathrm{dq}_{\mathrm{t}} / \mathrm{d}_{\mathrm{t}}=\mathrm{k}_{1}\left(\mathrm{q}_{\mathrm{e}}-\mathrm{q}_{\mathrm{t}}\right) & \ln \left(\mathrm{q}_{\mathrm{e}}-\mathrm{q}_{\mathrm{t}}\right)=\ln \mathrm{q}_{\mathrm{e}}-\mathrm{k}_{1} \mathrm{t} \\
\text { Pseudo-second-order } & \mathrm{dq}_{\mathrm{t}} / \mathrm{d}_{\mathrm{t}}=\mathrm{k}_{2}\left(\mathrm{q}_{\mathrm{e}}-\mathrm{q}_{\mathrm{t}}\right)^{2} & \mathrm{t} / \mathrm{q}_{\mathrm{t}}=1 / \mathrm{k}^{2} \mathrm{q}_{\mathrm{e}}{ }^{2}+\left(1 / \mathrm{q}_{\mathrm{e}}\right) \mathrm{t}
\end{array}
$$

Where, $\mathrm{q}_{\mathrm{e}}$ and $\mathrm{q}_{\mathrm{t}}$ refer to the amount of (MG) dye adsorbed $(\mathrm{mg} / \mathrm{g})$ at equilibrium and at any time, $\mathrm{t}(\mathrm{min})$, respectively and $\mathrm{k}_{1}(1 / \mathrm{min}), \mathrm{k}_{2}(\mathrm{~g} / \mathrm{mg} . \mathrm{min})$ are the equilibrium rate constants of pseudo-first order and pseudo-second order models, respectively. 
Pseudo-first order model is a simple kinetic model, which was proposed by Lagergren ${ }^{26}$ during 1898 and is used for estimation of the surface adsorption reaction rate. The values of $\ln \left(\mathrm{q}_{e}-\mathrm{q}_{t}\right)$ were linearly correlated with $t$. The plot of $\ln \left(\mathrm{q}_{\mathrm{e}}-\mathrm{q}_{\mathrm{t}}\right)$ vs. $t$ gave linear relationship from which the values of $\mathrm{k}_{1}$ were determined from the slope of the plot. In many cases, the first-order equation of Lagergren does not fit well with the entire range of contact time and is generally applicable over the initial stage of the adsorption processes $^{27}$.

In the pseudo-second order model ${ }^{28}$, the slope and intercept of the $t / q_{t} v s$. $t$ plot were used to calculate the second-order rate constant, $\mathrm{k}_{2}$. The values of equilibrium rate constant $\left(\mathrm{k}_{2}\right)$ are presented in Table 5. According to Table 5, the value of $\gamma(0.999)$ related to the pseudo-second order model revealed that (MG) dye adsorption followed this model, Nevertheless, pseudo-first order and pseudo-second order kinetic models cannot identify the mechanism of diffusion of dye into the adsorbent pores.

\section{Simple Elovich model}

The simple Elovich model is expressed in the form ${ }^{29}$,

$$
\mathrm{q}_{\mathrm{t}}=\alpha+\beta \ln \mathrm{t}
$$

Where, $\mathrm{q}_{\mathrm{t}}$ is the amount adsorbed at time t, $\alpha$ and $\beta$ are the constants obtained from the experiment. A plot of $\mathrm{q}_{\mathrm{t}}$ against $\ln \mathrm{t}$ should give a linear relationship for the applicability of the simple Elovich kinetic. The Elovich kinetics of MG dye on to ASI-NC for various initial concentrations $(25,50,75,100$ and $125 \mathrm{mg} / \mathrm{L})$ of volume $50 \mathrm{~mL}$ (each), adsorbent dose $0.025 \mathrm{~g}$, temperature $28{ }^{\circ} \mathrm{C}$ and $\mathrm{pH} 6.5$.

\section{Intra-Particle diffusion model}

The adsorption process on a porous adsorbent is generally a multi-step process. In order to analyse the mechanism of the adsorption of MG dye by ASI-NC, the experimental data were tested against the intra-particle diffusion model. The adsorption mechanism of the adsorbate on to the adsorbent follows three consecutive steps: mass transfer across the external film of liquid surrounding the particle, adsorption at the surface of pores and the intra-particle diffusion. The slowest of these steps determines the overall rate of the process. The possibility of intra-particle diffusion resistance which could affect the adsorption is explored by using the intra-particle diffusion model given in the equation,

$$
\mathrm{q}_{\mathrm{t}}=\mathrm{K} \mathrm{t}^{1 / 2}+\mathrm{I}
$$

Where, $\mathrm{K}$ is the intra-particle diffusion rate constant and $\mathrm{I}$ is the intercept. A plot of $\mathrm{q}_{\mathrm{t}}$ against $\mathrm{t}^{1 / 2}$ is drawn to analyse the possibility of intra-particle diffusion as the rate determining step. A two stage adsorption mechanism with first was rapid and second was slow has been observed from the experimental data. The plot of $\mathrm{q}_{\mathrm{t}}$ against $\mathrm{t}^{1 / 2}$ is multi-linear and deviating from the origin, indicating more than one process has affected the adsorption ${ }^{30}$. Hence, the first portion of the plot indicates the external mass transfer and the second portion is due to intra-particle or pore diffusion.

\section{Thermodynamic treatment of the sorption process}

In order to study the feasibility of the adsorption process, the thermodynamic parameters such as free energy, enthalpy and entropy changes can be estimated from the following equations.

$$
\begin{aligned}
\mathrm{K}_{\mathrm{c}} & =\mathrm{C}_{\mathrm{Ae}} / \mathrm{C}_{\mathrm{e}} \\
\Delta \mathrm{G}^{0} & =-\mathrm{RT} \ln \mathrm{K}_{\mathrm{c}} \\
\log \mathrm{K}_{\mathrm{c}} & =\Delta \mathrm{S}^{0} / 2.303 \mathrm{R}-\Delta \mathrm{H}^{0} / 2.303 \mathrm{RT}
\end{aligned}
$$


Where $C_{e}$ is the equilibrium concentration in solution in $m g / L$ and $C_{A e}$ is the equilibrium concentration on the sorbent in $\mathrm{mg} / \mathrm{L}$ and $\mathrm{K}_{\mathrm{c}}$ is the equilibrium constant. The Gibbs free energy $\left(\Delta \mathrm{G}^{0}\right)$ for the adsorption of MG onto biomass at all temperatures was obtained from Eq.25 and are presented in Table 4. The values of $\Delta \mathrm{H}^{0}$ and $\Delta \mathrm{S}^{0}$ were calculated from the slope and intercept of the plot $\log \mathrm{K}_{\mathrm{c}}$ against $1 / \mathrm{T}$ and are also listed in Table 4.

Table 4. Thermodynamic parameter for the adsorption of $(\mathrm{mg})$ dye onto ASI-NC

\begin{tabular}{ccccccccc}
\hline \multirow{2}{*}{$\left(\mathrm{C}_{0}\right)$} & \multicolumn{4}{c}{$\Delta \mathrm{G}^{\mathrm{o}}, \mathrm{kJ} / \mathrm{mol}$} & $\Delta \mathrm{H}^{\circ}$, & $\Delta \mathrm{S}^{\circ}$, & $\mathrm{Ea}$, & \multirow{2}{*}{$\mathrm{S}^{*}$} \\
\cline { 2 - 5 } $\mathrm{kJ} / \mathrm{mol}$ & $30{ }^{\circ} \mathrm{C}$ & $40{ }^{\circ} \mathrm{C}$ & $50{ }^{\circ} \mathrm{C}$ & $60{ }^{\circ} \mathrm{C}$ & $\mathrm{kJ} / \mathrm{mol}$ & \\
\hline 25 & -4146.7 & -5500.8 & -6526.7 & -6832.9 & 23.55 & 92.15 & 20884.6 & $3.8 \times 10^{-5}$ \\
50 & -3904.3 & -4282.4 & -4684.9 & -5483.3 & 11.59 & 50.87 & 9877.6 & $3.6 \times 10^{-3}$ \\
75 & -2859.8 & -3252.3 & -3763.9 & -4104.9 & 10.03 & 42.53 & 7893.1 & $1.1 \times 10^{-2}$ \\
100 & -2592.9 & -2956.6 & -3215.9 & -3516.9 & 6.596 & 30.40 & 5008.0 & $3.6 \times 10^{-2}$ \\
125 & -2049.7 & -2237.3 & -2385.9 & -2673.9 & 4.051 & 20.09 & 2870.0 & $10 \times 10^{-2}$ \\
\hline
\end{tabular}

In order to support that physical adsorption is the predominant mechanism, the values of activation energy (Ea) and sticking probability $\left(S^{*}\right)$ were calculated from the experimental data. They were calculated using modified Arrhenius type equation related to surface coverage $(\theta)$ as follows ${ }^{31}$ :

$$
\begin{gathered}
\theta=\left(1-\frac{\mathrm{C}_{\mathrm{e}}}{\mathrm{C}_{\mathrm{i}}}\right) \\
S^{*}=(1-\theta)_{e} \frac{-E_{a}}{R T}
\end{gathered}
$$

The sticking probability, $\mathrm{S}^{*}$, is a function of the adsorbate/adsorbent system under consideration but must satisfy the condition $0<\mathrm{S}^{*}<1$ and is dependent on the temperature of the system. The values of Ea and $S^{*}$ can be calculated from slope and intercept of the plot of $\ln (1-\theta)$ versus $1 / \mathrm{T}$ respectively and are listed in Table 4 .

From Table 4 it is clear that the reaction is spontaneous in nature as $\Delta \mathrm{G}^{0}$ values are negative at all the temperature studied. Again positive $\Delta \mathrm{H}^{\mathrm{o}}$ value confirms that the sorption is endothermic in nature. The positive value of $\Delta S^{0}$ reflects the affinities of the adsorbents for the (MG) dye. The value of Ea was found to be $9877 \mathrm{~kJ} \mathrm{~mol}^{-1}$ for the adsorption of MG dye onto biomass. The positive value of $\mathrm{E}_{\mathrm{a}}$ indicates the endothermic nature of the adsorption process which is in accordance with the positive values of $\Delta \mathrm{H}^{0}$. The result as shown in Table 4 indicate that the probability of the (MG) dye to stick on surface of biomass is very high as $\mathrm{S}^{*}<<1$, these values confirm that, the sorption process is physisorption ${ }^{32}$.

\section{Error analysis}

In the single-component isotherm studies, the optimization procedure requires an error function to be defined in order to be able to evaluate the fit of the isotherm to the experimental equilibrium data. However, the use of $\mathrm{R}^{2}$ is limited for solving the linear forms of the isotherm equation, but not the errors in isotherm curves. In this study, a Chi-square test was used. The Chi-square test statistic is basically the sum of the squares of the differences between the experimental data and data obtained by calculation from models, with each squared difference divided by the corresponding data obtained by calculation from models ${ }^{33}$. The equivalent mathematical statement is:

$$
X^{2}=\Sigma_{\mathrm{i}}=1^{\mathrm{m}}\left(\mathrm{q}_{\mathrm{e}, \exp }-\mathrm{q}_{\mathrm{e}, \mathrm{calc}}\right)^{2} / \mathrm{q}_{\mathrm{e}, \exp }
$$

Where, $\mathrm{q}_{\mathrm{e}, \exp }$ is the experimental data of the equilibrium capacity $(\mathrm{mg} / \mathrm{g}), \mathrm{q}_{\mathrm{e}}$,calc is the equilibrium capacity obtained by calculating from the model $(\mathrm{mg} / \mathrm{g})$. Therefore, it is necessary 
to analyze the data set using the Chi-square test to confirm the best-fit isotherm for the adsorption of (MG) on ASI-NC. Given the values of $\mathrm{R}^{2}$ and $\chi^{2}$ in Table 5 it can be concluded that the Freundlich isotherm model has the best goodness of fit among the applied isotherm models.

Table 5. The kinetic parameters for the adsorption of MG dye onto ASI-NC

\begin{tabular}{cccccccccccc}
\hline $\mathrm{C}_{0}$ & $\begin{array}{c}\text { Temp } \\
{ }^{\circ} \mathrm{C}\end{array}$ & \multicolumn{3}{c}{ Pseudo second order } & \multicolumn{3}{c}{ Elovich model } & \multicolumn{3}{c}{ Intraparticle diffusion } \\
\cline { 4 - 12 } & $\mathrm{q}_{\mathrm{e}}$ & $\mathrm{k}_{2}$ & $\gamma$ & $\mathrm{h}$ & $\alpha$ & $\beta$ & $\gamma$ & $\mathrm{K}_{\mathrm{id}}$ & $\gamma$ & $\mathrm{C}$ \\
\hline 25 & 30 & 49.78 & 0.0015 & 0.9918 & 3.763 & 11.98 & 0.107 & 0.975 & 0.273 & 0.997 & 1.427 \\
& 40 & 48.14 & 0.0036 & 0.9910 & 8.330 & 22.83 & 0.178 & 0.977 & 0.140 & 0.990 & 1.695 \\
& 50 & 48.06 & 0.0061 & 0.9938 & 14.12 & 33.97 & 0.266 & 0.981 & 0.087 & 0.992 & 1.804 \\
& 60 & 48.07 & 0.0065 & 0.9949 & 15.06 & 35.97 & 0.281 & 0.978 & 0.082 & 0.991 & 1.814 \\
50 & 30 & 91.86 & 0.0012 & 0.9971 & 10.37 & 83.71 & 0.074 & 0.982 & 0.188 & 0.995 & 1.567 \\
& 40 & 92.47 & 0.0014 & 0.9938 & 11.76 & 122.0 & 0.078 & 0.976 & 0.175 & 0.991 & 1.601 \\
& 50 & 93.38 & 0.0016 & 0.9964 & 13.73 & 191.7 & 0.082 & 0.978 & 0.162 & 0.990 & 1.637 \\
75 & 60 & 94.67 & 0.0018 & 0.9981 & 15.98 & 430.0 & 0.090 & 0.975 & 0.141 & 0.992 & 1.685 \\
& 30 & 121.9 & 0.0013 & 0.9921 & 19.84 & 775.8 & 0.074 & 0.976 & 0.132 & 0.996 & 1.630 \\
& 40 & 126.6 & 0.0015 & 0.9912 & 23.35 & 677.1 & 0.068 & 0.982 & 0.138 & 0.990 & 1.645 \\
& 50 & 132.1 & 0.0012 & 0.9904 & 21.42 & 721.2 & 0.058 & 0.981 & 0.158 & 0.992 & 1.624 \\
100 & 60 & 130.9 & 0.0018 & 0.9906 & 30.84 & 980.0 & 0.069 & 0.983 & 0.130 & 0.990 & 1.685 \\
& 30 & 159.7 & 0.0013 & 0.9925 & 33.60 & 633.5 & 0.051 & 0.980 & 0.148 & 0.994 & 1.613 \\
& 40 & 163.7 & 0.0012 & 0.9934 & 33.17 & 650.3 & 0.050 & 0.976 & 0.147 & 0.991 & 1.622 \\
& 50 & 165.4 & 0.0013 & 0.9955 & 36.29 & 875.2 & 0.051 & 0.979 & 0.141 & 0.996 & 1.641 \\
& 60 & 168.0 & 0.0013 & 0.9966 & 37.50 & 900.9 & 0.051 & 0.982 & 0.138 & 0.992 & 1.653 \\
125 & 30 & 187.1 & 0.0008 & 0.9953 & 26.85 & 517.0 & 0.043 & 0.977 & 0.151 & 0.992 & 1.556 \\
& 40 & 189.9 & 0.0008 & 0.9974 & 27.18 & 521.8 & 0.042 & 0.983 & 0.151 & 0.991 & 1.562 \\
& 50 & 190.3 & 0.0008 & 0.9921 & 29.46 & 711.3 & 0.045 & 0.981 & 0.141 & 0.992 & 1.585 \\
& 60 & 195.1 & 0.0007 & 0.9940 & 28.33 & 600.4 & 0.042 & 0.978 & 0.148 & 0.995 & 1.579 \\
\hline
\end{tabular}

\section{Discussion}

The present study investigated the efficiency of ASI-NC as a cheap adsorbent and the results revealed that ASI-NC was an appropriate adsorbent for removing MG from the aquatic environments. $\mathrm{pH}$ also plays a major role in removing the MG. The findings of the present study also showed that as the contact time increased, the dye's primary concentration as well as the dose of the intended adsorbate of the adsorption efficiency increased, as well. Adsorption equilibrium data follows Langmuir, Freundlich, Temkin and DubininRadushkevich isotherm models. The equilibrium data fitted very well in the Langmuir isotherm equation. The kinetic study of MG on to ASI-NC was performed based on pseudofirst-order, pseudo-second-order and intra-particle diffusion equations. The data indicate that the adsorption kinetics follow the pseudo-second-order rate. This study concludes that the ASI-NC could be employed as an appropriate, inexpensive, accessible and low-cost adsorbent for the removal of MG from aquatic environments.

\section{References}

1. Sapci Z and Ustun B, Elec J Environ Agric Food Chem., 2003, 2(2), 286-290.

2. Iqbal $\mathrm{M} J$ and Ashiq $\mathrm{M} \mathrm{N}, J$ Hazard Mater., 2007, 139(1), 57-66; DOI:10.1016/j.jhazmat.2006.06.007 
3. Yang J and Qiu K, Chem Eng J., 2010, 165(1), 209-217; DOI:10.1016/j.cej. 2010.09.019

4. Robinson T, McMullan G, Marchant R and Nigam P, Bioresour Technol., 2001, 77(3), 247-255; DOI:10.1016/S0960-8524(00)00080-8

5. Santhy K and Selvapathy P, Bioresour Technol., 2006, 97(11), 1329-1336; DOI:10.1016/j.biortech.2005.05.016

6. McKay G, Porter J F and Prasad G R, Water Air Soil Pollut., 1999, 114(3-4), 423-438; DOI:10.1023/A:1005197308228

7. Dogan M, Alkan M and Onganer Y, Water Air Soil Pollut., 2000, 120(3-4), 229-248; DOI:10.1023/A:1005297724304

8. Bereket G, Aro A Z and Ozel M Z, J Colloid Interface Sci., 1997, 187(2), 338-343; DOI:10.1006/jcis.1996.4537

9. Mohamed M M, Colloids Surf A: Physicochem Eng Aspect., 1996, 108(1), 39-48; DOI:10.1016/0927-7757(95)03381-5

10. Mohan D, Singh K P, Singh G and Kumar K, Indust Eng Chem Res., 2002, 41(15), 3688-3695; DOI:10.1021/ie010667+

11. Ho Y and McKay G, Chem Eng J., 1998; 70(2), 115-124; DOI:10.1016/S09230467(98)00076-1

12. McKay G, Otterburn M S and Sweeney A G, Water Res., 1981, 15(3), 327-331; DOI:10.1016/0043-1354(81)90036-1

13. Arivoli S, Marimuthu V and Jahangir A R M, Inter J Bioassays, 2015, 4(01), 36113617; DOI:10.21746/ijbio.2015.01.002

14. Arivoli S, Rose Judith T and Marimuthu V, Eur J Appl Sci Technol [EUJAST], 2014, 1(1), 15-22.

15. Arivoli S, Rose Judith T and Marimuthu V, Res Rev J Chem., 2014, 3(1), 15-22.

16. Langmuir I, J American Chem Soc., 1918, 40(9), 1361-403; DOI:10.1021/ja 02242a004

17. Abdelwahab O, Desal., 2008, 222(1), 357-367; DOI:10.1016/j.desal.2007.01.146

18. Ng C, Losso J N, Marshall W E and Rao R M, Bioresour Technol., 2002, 85(2), 131135; DOI:10.1016/S0960-8524(02)00093-7

19. Akbal F, J Colloid Interface Sci., 2005, 286(2), 455-458; DOI:10.1016/j.jcis. 2005.01.036

20. Asgari G, Roshani B and Ghanizadeh G, J Hazard Mater., 2012, 217-218, 123-132; DOI:10.1016/j.jhazmat.2012.03.003

21. Freundlich H, Leipzig, 1906, 57(A), 385-470.

22. Temkin M J and Pyzhev V, Acta Physiochim USSR., 1940, 12, 217-222.

23. Dubinin M M, Zaverina E D and Radushkevich LV, Zhurnal Fizicheskoi Khimii., 1947, 21, 1351-1362.

24. Rieman W and Walton H, Ion Exchange in Analytical Chemistry, International Series of Monographs in Analytical Chemistry. Pergamon Press, Oxford; 1970.

25. Altenor S, Carene B, Emmanuel E, Lambert J, Ehrhardt J J and Gaspard S, J Hazard Mater., 2009, 165(1-3), 1029-1039; DOI:10.1016/j.jhazmat.2008.10.133

26. Colak F, Atar N and Olgun A, Chem Eng J., 2009, 150(1), 122-130; DOI:10.1016/j.cej.2008.12.010

27. Murugan T, Ganapathi A and Valliappan R, J Chem., 2010, 7(3), 669-676; DOI: $10.1155 / 2010 / 127020$

28. Lagergren S, Handlingar, 1898, 24(4), 1-39. 
29. Ahmad A A, Hameed B H and Aziz N, J Hazard Mater., 2007, 141(1), 70-76; DOI:10.1016/j.jhazmat.2006.06.094

30. Ho Y and McKay G, Proc Biochem., 1999, 34(5), 451-465; DOI:10.1016/S00329592(98)00112-5

31. Weber W J and Morris J C, J Sanit Eng Div Am Soc Civ Eng., 1963, 89(17), 31-60.

32. Mall I D, Srivastava V C and Agarwal N K, Dyes Pigments, 2006, 69(3), 210-223; DOI:10.1016/j.dyepig.2005.03.013

33. Amin N K, J Hazard Mater., 2009; 165(1-3), 52-62; DOI:10.1016/j.jhazmat. 2008.09.067 